\title{
Population dynamics, distribution and secondary production of the brown shrimp Crangon crangon (L.) in a southern European estuary. Latitudinal variations
}

\author{
IVAN VIEGAS, FILIPE MARTINHO, JOÃO NETO and MIGUEL PARDAL \\ Institute of Marine Research (IMAR), c/o Department of Zoology, University of Coimbra, 3004-517 Coimbra, Portugal. \\ E-mail: iviegas@ci.uc.pt
}

\begin{abstract}
SUMMARY: The population structure, growth, distribution and secondary production of the brown shrimp Crangon crangon (L. 1758) were examined between June 2003 and August 2005 at five stations in the Mondego Estuary, Portugal, using a 2-m beam trawl. Occurrence of immature shrimps suggested almost continuous reproduction with two main recruitment periods in November and March/April; this recruitment pattern is unique and represents a latitudinal transition in the species' life cycle. Severe drought in winter 2004 caused spatial shifts along the north arm of the estuary regarding post-larval settlement in spring 2005. Mean growth of all cohorts was $0.06 \mathrm{~mm}$ TL day ${ }^{-1}$, much lower than rates calculated elsewhere. Secondary production (P) of $C$. crangon was estimated at $4.6 \mathrm{mg} \mathrm{AFDW} \mathrm{m}^{-2} \mathrm{y}^{-1}(\mathrm{P} / \overline{\mathrm{B}}$ ratio of 8.7) in 2003/2004 and at 2.4 $\mathrm{mg}$ AFDW m $\mathrm{m}^{-2} \mathrm{y}^{-1}(\mathrm{P} / \overline{\mathrm{B}}$ ratio of 10.9$)$ in $2004 / 2005$. High abundances of individuals, predominantly juveniles, were observed in spring/summer with peaks in June 2003, April 2004 and July 2005. This study shows that this species dynamics must be analysed in a latitudinal context, meaning that the contribution of each component of the systems can vary according to environmental and climate variables.
\end{abstract}

Keywords: Crangon crangon, Mondego estuary, population dynamics, secondary production, latitudinal variations.

RESUMEN: DINÁMICA DE POBLACIONES, DISTRIBUCIÓN Y PRODUCCIÓN SECUNDARIA DE LA QUISOUILLA CRANGON CRANGON (L.) EN UN ESTUARIO DEL SUR DE EUROPA. VARIACIONES LATITUDINALES. - Entre Junio de 2003 y Agosto de 2005 se estudió la estructura de la población, crecimiento, distribución y producción secundaria de la quisquilla Crangon crangon (L, 1758) en cinco estaciones del estuario del río Mondego, Portugal, usando una red de arrastre de dos metros (beam trawl). La presencia de juveniles sugiere una reproducción casi constante con dos periodos principales de reclutamiento en Noviembre y Marzo/Abril; este patrón de reclutamiento es único y representa una transición latitudinal en el ciclo de vida de esta especie. La grave sequía del invierno de 2004 causó desplazamientos espaciales a lo largo del brazo norte del estuario, teniendo en cuenta el asentamiento postlarvario en la primavera de 2005. El crecimiento medio de las cohortes fue de $0.06 \mathrm{~mm}_{\text {TL día }}^{-1}$, muy inferior al registrado en otros lugares. La producción secundaria (P) estimada para C. crangon fue de $4.6 \mathrm{mg}$ AFDW $\mathrm{m}^{-2} \mathrm{y}^{-1}$ (relación P/B de 8.7) en 2003/2004 y de 2.4 mg AFDW m ${ }^{-2} \mathrm{y}^{-1}$ (relación P/B de 10.9) en 2004/2005. Se observaron altas abundancias de individuos, predominantemente juveniles, en primavera/verano con picos en Junio de 2003, Abril de 2004 y Julio de 2005. Este estudio muestra que la dinámica de poblaciones de esta especie debe ser analizada en un contexto latitudinal, es decir, considerando que la contribución de cada componente del sistema puede variar dependiendo de variables ambientales y climáticas.

Palabras clave: Crangon crangon, estuario del río Mondego, dinámica de poblaciones, producción secundaria, variaciones latitudinales.

\section{INTRODUCTION}

The brown shrimp Crangon crangon (Linnaeus, 1758) occurs in highly productive European estuaries (between $45^{\circ} \mathrm{N}$ and $57^{\circ} \mathrm{N}$ ) with strong tidal movements on sandy and muddy substrata (Tiews, 1970). It is the dominant mobile epibenthic species in northern Europe (e.g. Pihl and Rosenberg, 1982; Beyst et al., 2002; Amara and Paul, 2003). Due to its abundance, $C$. crangon is an important prey for 


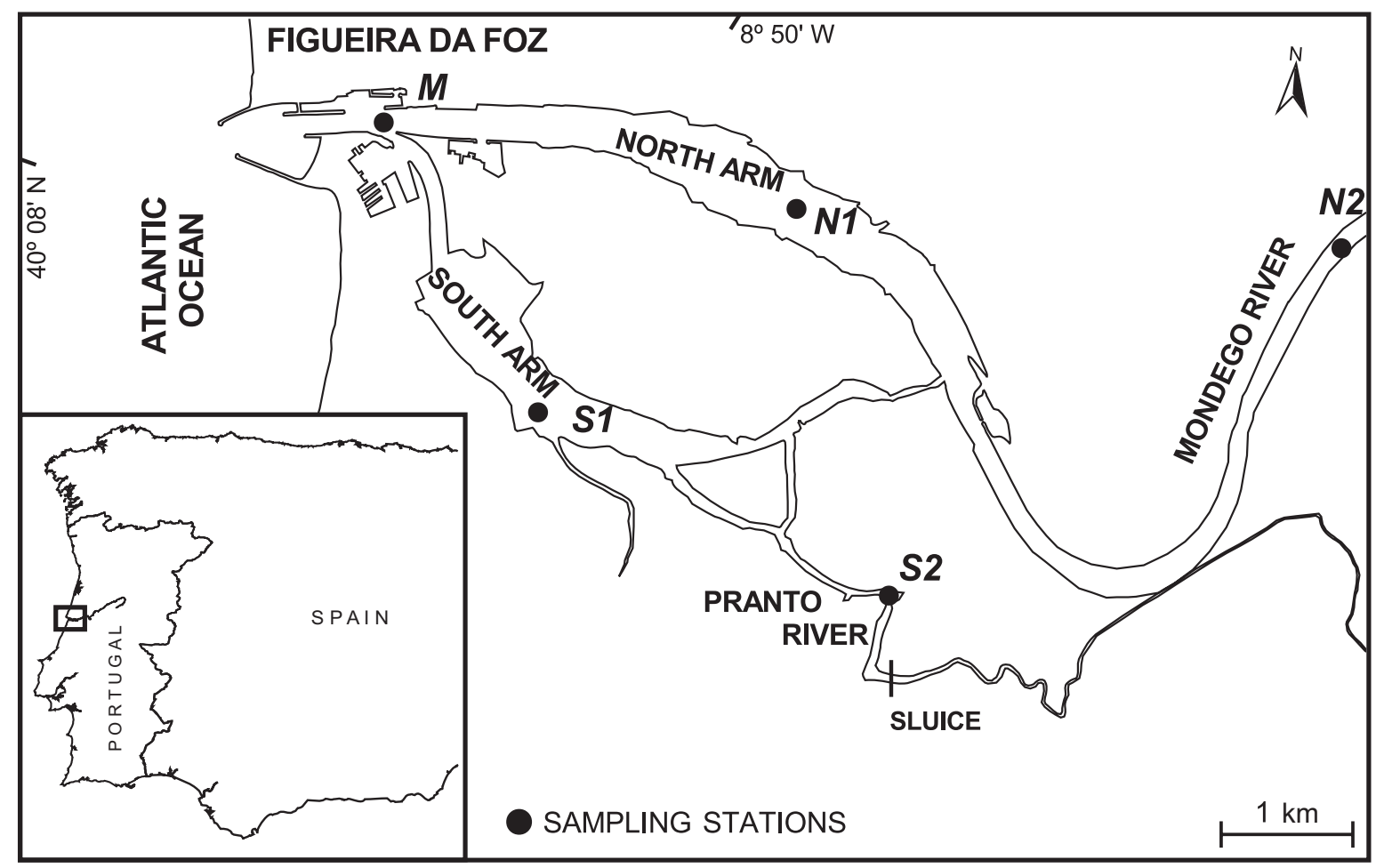

FIG. 1. - Location of sampling stations in the Mondego estuary.

juvenile and adult fish species (McLusky and Elliott, 2004) and also an important benthic predator of invertebrates (Pihl and Rosenberg, 1984; Beukema, 1992; Oh et al., 2001). Through its predation of invertebrates (Kamermans and Huitema, 1994; Beukema and Dekker, 2005) and interference with settlement of juvenile fish (Wennhage and Gibson, 1998), this species' impact upon the structure and function of the in- and epifauna (Kuipers and Dapper, 1981; Pihl, 1985) reflects its importance on estuarine systems.

$C$. crangon has commercial value, so abundance (Pihl and Rosenberg, 1982; Spaargaren, 2000; Siegel et al., 2005), fisheries by-catch and discards (Berghahn et al., 1992; Berghahn and Purps, 1998; Gamito and Cabral, 2003) and migratory behaviour (Hartsuyker, 1966; Boddeke, 1976; Janssen and Kuipers, 1980) have been extensively studied. It is caught primarily along the coastline of countries bordering the North Sea by twin beam trawlers, and the total value of landings in 1997 was estimated at 98.2 million euros (Pascoe and Revill, 2004). Beam trawl is an illegal fishing gear in Portuguese estuaries except in the Tagus Estuary (Cabral et al., 2002). Recently, due to the decrease in the market value of this species, sole (Solea spp.) and sea bass (Dicentrarchus labrax), have been the only prof- itable by-catch species of the brown shrimp fishery in Portugal (Costa and Cabral, 1999).

The main reproductive season of this species goes from January to June, with potential for continuous breeding during this period ( $\mathrm{Oh}$ and Hartnoll, 2004). Nevertheless, two reasonably discrete spawning periods (Henderson and Holmes, 1987) which can overlap have been described (Lloyd and Yonge, 1947). In spring, after hatching offshore, pelagic larvae migrate to coastal waters (van Donk and De Wilde, 1981), developing into benthic post-larvae that invade estuaries and shallow inshore waters where abundant food sources are available (Beukema, 1992). Juvenile settlement can last until October, with abundance peaks in MayAugust (Amara and Paul, 2003). Juveniles occupy these areas permanently while adults migrate back to the sea in autumn when the temperature begins to drop (Boddeke, 1976). Despite these data, some latitudinal differences have been reported for the Mediterranean Sea (Labat, 1977; Crivelli, 1982) but fewer studies have addressed global patterns of this species.

Due to its importance in estuarine systems and the need to document $C$. crangon in temperate estuaries, namely at its southern limit of distribution in the Atlantic coastal waters, the purpose of the pres- 
ent study was: (a) to describe the species' life cycle, population structure and growth, (b) to compare the results obtained with those of other European populations, (c) to study the spatial distribution and variability of the species along an estuarine salinity gradient, and (d) to estimate C. crangon secondary production.

\section{MATERIAL AND METHODS}

\section{Sampling site}

The Mondego Estuary (Fig. 1) is a typical temperate intertidal estuary located on the west coast of Portugal $\left(40^{\circ} 08^{\prime} \mathrm{N}, 8^{\circ} 50^{\prime} \mathrm{W}\right)$; it consists of two arms with very different hydrologic features that separate 7 $\mathrm{km}$ from the sea and join again near the mouth, divided by an alluvium-formed island (Murraceira island). The north arm is deeper (5-10 m during high tide, tidal range about 2-3 m), while the south arm (2-4 m deep during high tide) is almost silted up in upstream areas, which causes the freshwater of the river to flow essentially along the north arm. The water circulation in the south arm is dependent on tides and on the relatively small freshwater input from a tributary, the Pranto River, which is controlled by a sluice. The freshwater discharge from this tributary is regulated according to irrigation needs of the rice crop of Pranto valley (Pardal et al., 2000; Martins et al., 2001). The Mondego Estuary has suffered from the impact of human activities, besides supporting several industries, salt-works and aquaculture farms. The north arm forms the main navigation channel and requires regular dredging. In the south arm, eutrophication has taken place as a result of excessive nutrient release leading to reduction in area extent, biomass and production of the seagrass Zostera noltii bed (Cardoso et al., 2002, 2005; Dolbeth et al., 2003; Pardal et al., 2004). The study area has already been described as a nursery area for fish species like Dicentrarchus labrax, Solea solea, Platichthys flesus (Martinho, in press), Pomatoschistus microps and Pomatoschistus minutus (Leitão et al., 2006), and for benthic macroinvertebrates like Carcinus maenas (Baeta et al., 2005).

\section{Sampling procedures}

Samples of the brown shrimp were collected from five stations (Fig. 1). Fishing took place monthly, during the night, from June 2003 to August 2005 (except in Autumn 2004) at high water of spring tides due to high water transparency and better gear efficiency. The gear used was a $2 \mathrm{~m}$ by 0.5 $\mathrm{m}$ beam trawl with a tickler chain and $5 \mathrm{~mm}$ meshsize at the cod-end. Three trawls were towed for an average of 5 minutes each at all sampling stations, covering at least an area of $500 \mathrm{~m}^{2}$. Bottom water temperature, salinity, dissolved oxygen and depth were measured during sampling at all sampling stations. The sediment of the sampling areas was characterised based on samples collected in the summer and autumn of 2003 and the winter and spring of 2004 using a van Veen grab.

\section{Sample analysis}

After sorting, the algae collected together with fish in beam trawl samples were weighed (total wet weight) and the shrimps were preserved in $4 \%$ formaldehyde for a day before being transferred to $70 \%$ ethanol for storage. Carapace length (CL), the shortest distance between the posterior margin of the orbit and the mid-dorsal posterior edge of the carapace, was measured to the nearest $0.01 \mathrm{~mm}$ using a binocular micrometer. Total length (TL) was measured from the posterior margin of the orbit to the tip of the telson. The following regression between TL and CL was calculated, allowing comparisons with other studies:

$$
\mathrm{TL}=4.7906 * \mathrm{CL}-1.1295\left(\mathrm{r}^{2}=0.98, \mathrm{~N}=702\right) .
$$

Sex was determined by the size and shape of the endopodite of the first pleopod and the presence or absence of the appendix masculina. Sex determination for shrimps $\mathrm{CL}<3.5 \mathrm{~mm}$ was inconclusive and these individuals were considered as immature. Biomass was calculated as ash-free dry weight (AFDW) (loss of ignition after $8 \mathrm{~h}$ of incineration at $450^{\circ} \mathrm{C}$ of specimens previously dried at $60^{\circ} \mathrm{C}$ for 2 days). The weight-length relationship was calculated for production estimates as:

$$
\mathrm{AFDW}=0.0002 * \mathrm{CL}^{3.0725}\left(\mathrm{r}^{2}=0.98, \mathrm{~N}=277\right)
$$

with exponent close to 3.0 indicating isometric growth. Dried sediment samples were incinerated at $450^{\circ} \mathrm{C}$ and then sorted in a sieve series and weighed according to grain size to assess the granulometry. 


\section{Data analysis}

Population structure and growth was based on size-frequency distributions and studied through modal analysis on successive sample dates. Computations were performed using the ANAMOD software (Nogueira, 1992), which is based on the probability paper method (Cassie, 1963). The reliability of the method was tested by employing the $\mathrm{G}$ e $\chi^{2}$ tests $(\mathrm{P} \leq 0.05)$. Only 5 individuals $\mathrm{CL}>11 \mathrm{~mm}$ were found during the sampling (on 4 different months), so, due to their low and sparse frequency these individuals were not included in the analysis.

A canonical correspondence analysis (CCA) was used to evaluate the spatial and temporal distribution of $C$. crangon with environmental parameters using CANOCO 4.5 (Ter Braak and Smilauer, 1998). Species data were separated by sex (immature, males, females and berried females); females and berried females were also separated by size $(C L<7.7$ $\mathrm{mm}$ and CL>7.7 $\mathrm{mm}$ ), since no male individuals were found bigger than this measure. Temperature, salinity, dissolved oxygen, type of sediment, algae biomass and mean depth were computed in the analysis as environmental data. All input data were averaged by sampling area (stations $\mathrm{M}, \mathrm{S} 1, \mathrm{~S} 2, \mathrm{~N} 1$ and N2) and season (summer; $n=3$, autumn, winter and spring; $\mathrm{n}=2$ ).

Annual production estimates were based upon cohort recognition by growth increments or net production (P), as described in Cardoso (2002)

$$
P=\sum_{t=0}^{t=n}\left(\frac{N_{t}+N_{t+1}}{2}\right) \times\left(\bar{w}_{t+1}-\bar{w}_{t}\right),
$$

where $\mathrm{P}$ is production; $\mathrm{N}$ mean density (expressed in ind $\mathrm{m}^{-2}$ ); $\overline{\mathrm{w}}$, mean individual body weight (expressed in $\mathrm{g}$ AFDW $\mathrm{m}^{-2}$ ) and $\mathrm{t}, \mathrm{t}+1$ are consecutive sampling dates $(\mathrm{t}=1,2, \ldots, \mathrm{n})$. The annual mean population biomass $(\overline{\mathrm{B}})$ is expressed as:

$$
\bar{B}=(1 / T) \sum_{n=1}^{N}\left(\bar{B}_{n} t\right),
$$

where $T$ is the period of study (yearly cycles); $\bar{B}_{n}$ is the mean biomass of cohort $\mathrm{n}$ and $\mathrm{t}$ is the duration of the cohort $n$.

\section{RESULTS}

\section{Characterisation of the sampling areas}

Most of the environmental variables measured at the sampling sites (Table 1) confirmed the estuarine gradient, from the upper areas to the mouth of the estuary. Temperature exhibited a typical seasonal pattern for a temperate region, reaching higher values in uppermost sampling areas, which are also the shallowest. Stations M, S1 and N1 presented the highest salinity values, while dissolved oxygen showed a similar pattern with both temperature and depth. Although Secchi depth was not measured (as the surveys took place at night), high turbidity was found at station S2 (Verdelhos et al., 2005). The sediment of the most upstream areas was mostly composed of medium and coarse sand, contrasting with the downstream ones which consisted mainly of medium to fine sand, with larger amounts of mud at station S2.

Hydrological years (from October to September) were found to be different as the winter of 2004 was exceptionally dry. The hydrological year of 2004/2005 was considered atypical due to severe drought, since rainfall in the Mondego river basin area was $45-60 \%$ below average (data from the

TABLE 1. - Mean monthly values ( \pm SD) of water temperature $\left({ }^{\circ} \mathrm{C}\right)$, salinity, dissolved oxygen $(\%)$, percentage of large sand, medium sand, fine sand, silt and mud in the sediment, algae cover $\left(\mathrm{g} \mathrm{m}^{-2}\right)$ and depth $(\mathrm{m})$ per sampling station on 2003/2004 and 2004/2005 hydrologic years

\begin{tabular}{|c|c|c|c|c|c|c|c|c|c|c|}
\hline \multirow[t]{2}{*}{ Sampling station } & \multicolumn{2}{|c|}{ M } & \multicolumn{2}{|c|}{$\mathrm{S} 1$} & \multicolumn{2}{|c|}{$\mathrm{S} 2$} & \multicolumn{2}{|c|}{$\mathrm{N} 1$} & \multicolumn{2}{|c|}{$\mathrm{N} 2$} \\
\hline & 03 | 04 & $04 \mid 05$ & $03 \mid 04$ & $04 \mid 05$ & $03 \mid 04$ & $04 \mid 05$ & $03 \mid 04$ & $04 \mid 05$ & $03 \mid 04$ & $04 \mid 05$ \\
\hline Temperature & $14.7 \pm 1.8$ & $14.9 \pm 3.4$ & $15.6 \pm 1.9$ & $15.1 \pm 3.9$ & $16.4 \pm 4.6$ & $17.8 \pm 6.5$ & $15.6 \pm 2.9$ & $15.8 \pm 4.6$ & $16.0 \pm 5.0$ & $16.9 \pm 6.3$ \\
\hline Salinity & $30.9 \pm 3.3$ & $32.0 \pm 2.3$ & $28.7 \pm 5.3$ & $32.1 \pm 4.7$ & $21.9 \pm 5.0$ & $28.5 \pm 4.8$ & $22.2 \pm 6.2$ & $25.9 \pm 5.6$ & $2.2 \pm 2.6$ & $11.0 \pm 7.5$ \\
\hline Dissolved $\mathrm{O}_{2}$ & $99.8 \pm 11.7$ & $101.8 \pm 11.0$ & $96.3 \pm 6.5$ & $98.4 \pm 8.2$ & $86.9 \pm 9.9$ & $86.0 \pm 10.7$ & $94.4 \pm 6.5$ & $93.5 \pm 7.4$ & $90.0 \pm 13.8$ & $89.6 \pm 7.1$ \\
\hline Large sand & $14.3 \pm 20.1$ & $11.2 \pm 11.1$ & $44.7 \pm 18.8$ & $40.6 \pm 9.2$ & $12.4 \pm 15.6$ & $27.6 \pm 36.6$ & $40.0 \pm 27.1$ & $37.1 \pm 27.9$ & $79.4 \pm 5.5$ & $57.3 \pm 48.7$ \\
\hline Medium sand & $24.4 \pm 13.5$ & $36.4 \pm 15.3$ & $22.1 \pm 6.5$ & $36.0 \pm 13.3$ & $21.7 \pm 7.0$ & $28.2 \pm 1.6$ & $58.2 \pm 26.2$ & $58.1 \pm 25.2$ & $19.3 \pm 5.2$ & $13.7 \pm 1.4$ \\
\hline Fine sand & $50.6 \pm 21.3$ & $52.1 \pm 20.8$ & $29.2 \pm 11.0$ & $21.0 \pm 19.1$ & $50.4 \pm 9.7$ & $30.9 \pm 24.7$ & $1.8 \pm 1.2$ & $4.8 \pm 2.8$ & $1.0 \pm 0.3$ & $14.4 \pm 23.0$ \\
\hline Silt & $8.4 \pm 9.4$ & $0.2 \pm 0.1$ & $3.3 \pm 1.0$ & $2.3 \pm 3.3$ & $13.3 \pm 6.0$ & $12.6 \pm 11.3$ & $0.0 \pm 0.0$ & $0.1 \pm 0.0$ & $0.2 \pm 0.1$ & $12.0 \pm 20.0$ \\
\hline Mud & $2.3 \pm 2.7$ & $0.0 \pm 0.1$ & $0.8 \pm 0.6$ & $0.1 \pm 0.2$ & $2.1 \pm 1.5$ & $0.7 \pm 0.6$ & $0.0 \pm 0.0$ & $0.0 \pm 0.0$ & $0.0 \pm 0.1$ & $2.6 \pm 4.3$ \\
\hline Algae cover & $0.20 \pm 0.17$ & $0.27 \pm 0.32$ & $0.63 \pm 1.26$ & $4.14 \pm 3.48$ & $3.01 \pm 3.27$ & $3.87 \pm 3.85$ & $0.01 \pm 0.04$ & $0.11 \pm 0.1$ & $0.01 \pm 0.01$ & $0.03 \pm 0.05$ \\
\hline Depth & $8.6 \pm 1.3$ & $9.1 \pm 0.9$ & $2.3 \pm 0.5$ & $2.3 \pm 0.2$ & $2.1 \pm 1.1$ & $2.1 \pm 0.7$ & $5.5 \pm 0.5$ & $5.6 \pm 0.3$ & $3.8 \pm 0.6$ & $4.0 \pm 0.4$ \\
\hline
\end{tabular}
(from October to September). 


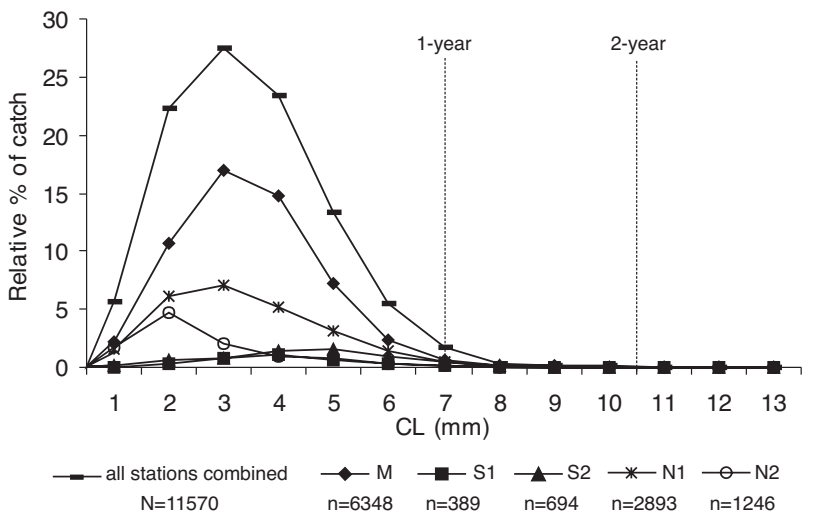

FIG. 2. - Size structure from catches of Crangon crangon at each sampling station (M, S1, S2, N1 and N2) during the study period.

Meteorological Institute of Portugal). The MannWhitney test revealed significant differences between hydrological years regarding salinity at stations $\mathrm{S} 2$ and $\mathrm{N} 2$, the uppermost stations of each arm $(\mathrm{p}=0.0186$ and $\mathrm{p}=0.0093$ respectively for $\alpha=0.05$ ). Differences were also found in algal biomass at stations $\mathrm{S} 1$ and $\mathrm{N} 1$ ( $\mathrm{p}=0.0041$ and $\mathrm{p}=0.0187$ respectively for $\alpha=0.05$ ).

\section{Population dynamics and growth}

During this study, a total of 11570 individuals were examined; 4675 immature ones, 4091 females
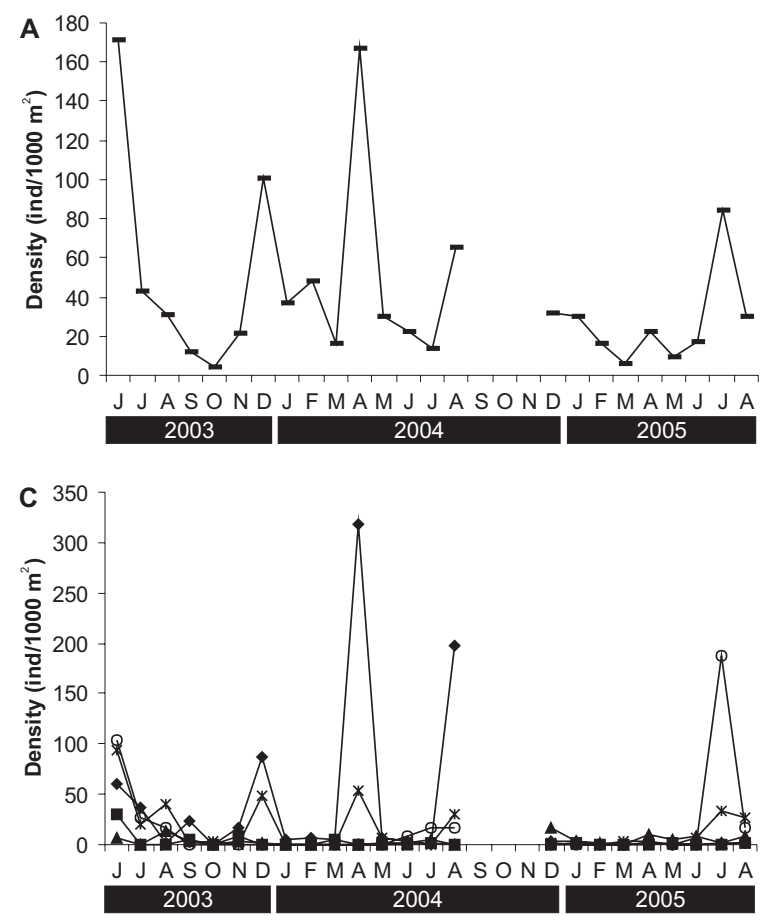

(240 berried females) and 2804 males. Most were captured at stations $\mathrm{M}$ and $\mathrm{N} 1,55 \%$ and 25\% respectively of total sampling (Fig. 2). Smallest post-larvae occurred at $1.23 \mathrm{~mm} \mathrm{CL} \mathrm{(5} \mathrm{mm} \mathrm{TL)} \mathrm{and}$ the biggest individual was a female of $13.00 \mathrm{~mm} \mathrm{CL}$ (61 mm TL) caught in December 2003. Berried females ranged from 4.29 to $12.86 \mathrm{~mm}$ CL and only 5 of the 240 berried females found corresponded to "winter egg" production (see Boddeke, 1982). The size at onset of sexual maturity ( $>5 \%$ mature) was within the 5.00-5.25 mm CL class reaching sexual maturity after 6 months of age.

Occurrence of immature shrimps suggested almost continuous reproduction, but two main recruitment periods per year were identified (Fig. 3): one in autumn with settlement of post-larvae beginning in November, and one in spring with settlement beginning in March/April. It is possible, and most likely, that in the summer another recruitment takes place, but this reproductive pulse was not identifiable by the modal analysis.

Results from modal analysis (all stations combined) computed separately for gender indicated that, as in other regions, females grow larger than males; no males bigger than $7.7 \mathrm{~mm}$ CL were found and only 90 females exceeded this size, corresponding to only $0.8 \%$ of the total sampling. Growth of
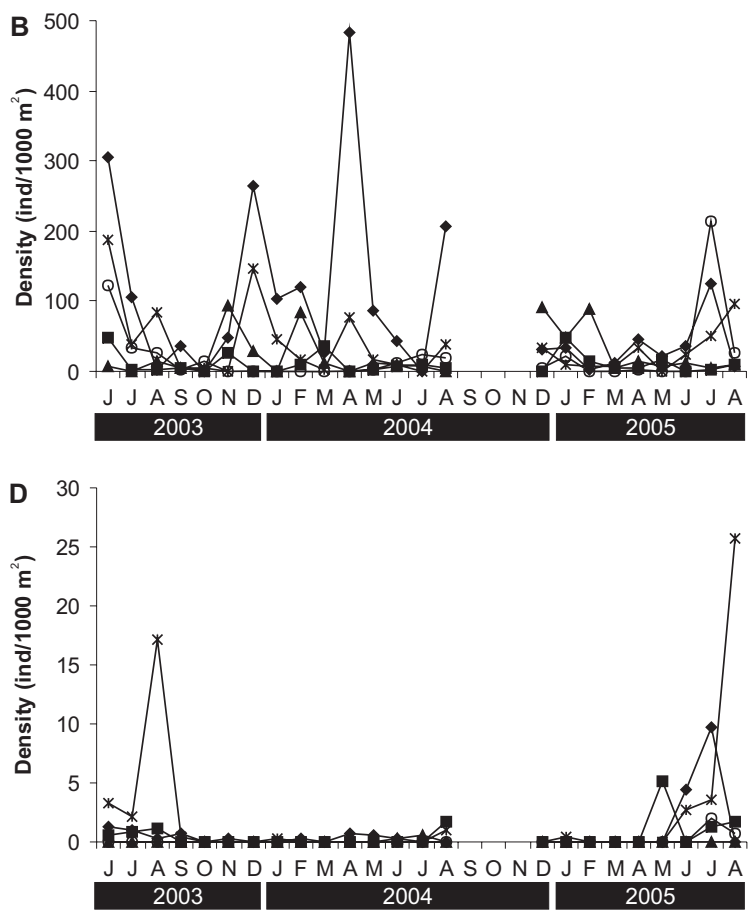

FIG. 3. - Crangon crangon densities during the study period: total density of all sampling stations combined (A), total density at each sampling station (B), immature shrimp density (C) and berried female density (D). 


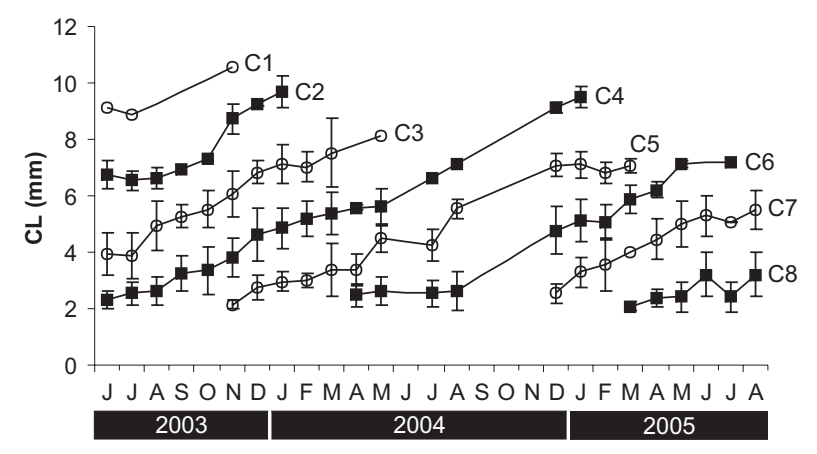

FIG. 4. - Crangon crangon estimated growth for each cohort (all sampling stations combined) during the study period.

immature shrimps was estimated at $0.07 \mathrm{~mm} \mathrm{CL}$ day $^{-1}$ for the spring/summer cohorts and $0.08 \mathrm{~mm}$ $\mathrm{CL}$ day $^{-1}$ for the autumn cohorts; mean growth of all cohorts was $0.06 \mathrm{~mm} \mathrm{CL} \mathrm{day}^{-1}$.

Based on cohort analysis (Fig. 4) after one year individuals ranged from $6.20 \mathrm{~mm} \mathrm{CL} \pm 0.28$ (C6) to $7.09 \mathrm{~mm} \mathrm{CL} \pm 0.41$ (C5) (30-32 mm TL) and two year old shrimps reached $10.53 \mathrm{~mm} \mathrm{CL} \pm 0.85$ (C1), approximately $49 \mathrm{~mm}$ TL. Five individuals caught with CL $>11 \mathrm{~mm}$ were not included for modal analysis purposes: their isolated inclusion would be speculative and this would alter the calculations of the growth rates. Based on these data, the maximum life span of $C$. crangon was estimated at 3 years.

\section{Distribution and abundance patterns}

High abundances of individuals were observed in spring/summer with peaks in June 2003, April 2004 and July 2005 (densities of 305, 484 and 214 ind $/ 1000 \mathrm{~m}^{2}$, respectively). These peaks were dominated by juveniles and occurred mainly in the north arm (station M in June 2003 and April 2004, and station N2 in July 2005). A smaller density peak was observed in December, ranging from 263 ind/1000 $\mathrm{m}^{2}$ in 2003 to $91 \mathrm{ind} / 1000 \mathrm{~m}^{2}$ in 2004 (Fig. 3). Station $M$ registered the highest densities of all types of specimens except for berried females, which occurred mainly at N1. On the other hand, the lowest densities of shrimps were found in the south arm of the estuary, including the complete absence of berried females at station S2. Station N2 registered high densities of immature shrimps but was characterised by almost complete males (Table 2).

Despite its wide distribution within the Mondego Estuary, C. crangon showed some spatial, temporal and environmental preferences (Fig. 5). The first
TABLE 2. - Mean values ( \pm SD) for population density at each sampling station during the study period (densities presented in ind $\left./ 1000 \mathrm{~m}^{-2}\right)$.

\begin{tabular}{lccccc}
\hline & \multicolumn{5}{c}{ Sampling station } \\
& M & S1 & S2 & N1 & N2 \\
\hline Female & $35 \pm 39$ & $4 \pm 6$ & $15 \pm 24$ & $10 \pm 11$ & $5 \pm 6$ \\
Male & $25 \pm 29$ & $4 \pm 7$ & $5 \pm 10$ & $12 \pm 16$ & $1 \pm 1$ \\
Immature & $35 \pm 78$ & $2 \pm 6$ & $4 \pm 5$ & $17 \pm 25$ & $17 \pm 43$ \\
Ovigerous & $1 \pm 2$ & $1 \pm 1$ & $0 \pm 0$ & $3 \pm 6$ & $0 \pm 0$ \\
Total & $96 \pm 121$ & $11 \pm 15$ & $24 \pm 33$ & $42 \pm 49$ & $22 \pm 49$ \\
\hline
\end{tabular}

two axes of the canonical correspondence analysis (CCA) performed in order to evaluate distribution and abundance patterns accounted for $81.6 \%$ of the total variance (eigenvalues of 0.320 and 0.261 , respectively) and $85.5 \%$ of the variance due to species abundance-environment relations. The ordination diagram of the first 2 axes showed that the points found to the left of the diagram are strongly related to temperature. Females with a CL>7.7 mm (F) were associated with cold seasons while berried females with a $\mathrm{CL}<7.7 \mathrm{~mm}(o)$ and immature individuals $(I)$ were associated with warm seasons. Peak abundance of berried females was observed in $\stackrel{\circ}{-}$

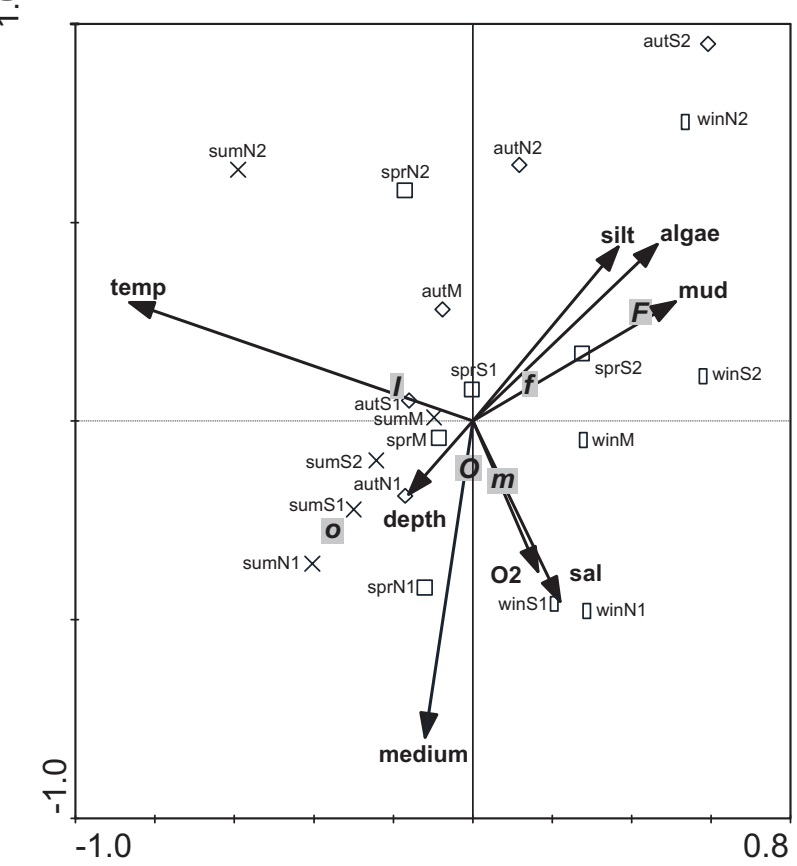

FIG. 5. - Ordination diagram for the two canonical axes of the correspondence analysis performed using Crangon crangon density data (I, immature $\mathrm{CL}<3.5 \mathrm{~mm} ; f$, female $\mathrm{CL}<7.7 \mathrm{~mm} ; F$, female CL $>7.7$ $\mathrm{mm} ; m$, male; $o$, berried female $\mathrm{CL}<7.7 \mathrm{~mm} ; O$, berried female CL $>7.7 \mathrm{~mm}$; temp, temperature; sal, salinity; algae, algae cover; mud, $\%$ of mud; silt, $\%$ of silt; medium, $\%$ of medium sand; O2, dissolved oxygen; sum, summer; aut, autumn; win, winter; spr, spring; M, sampling station M; S1, sampling station S1; S2, sampling station S2; N1, sampling station N1; N2, sampling station N2). 
August, mostly at station N1 (Fig. 3). Immature individuals were sensitive to temperature and tolerant to salinity and dissolved oxygen, while males showed the opposite trend, with rare occurrence at the upper sampling stations. On the other hand, females were distributed according to type of sediment and algal cover.

\section{Production estimates}

Calculations were made excluding station $\mathrm{S} 1$ and S2, whose contributions were the lowest in the total sampling (3 and 6\% respectively). The average annual growth production $(\mathrm{P})$ of the $C$. crangon population was estimated at $4.6 \mathrm{mg}^{\mathrm{AFDW}} \mathrm{m}^{-2} \mathrm{y}^{-1}(\mathrm{P} / \overline{\mathrm{B}}$ ratio of 8.7) in 2003/2004 and $2.4 \mathrm{mg}^{\mathrm{AFDW} \mathrm{m}} \mathrm{m}^{-2} \mathrm{y}^{-1}(\mathrm{P} / \overline{\mathrm{B}}$ ratio of 10.9) in 2004/2005.

\section{DISCUSSION}

\section{Population dynamics and growth}

Drought-induced changes in water quality are known to influence the distribution of $C$. crangon (Attrill and Power, 2000). In the present study the differences between hydrological years were not analysed, allowing the characterisation of the species dynamics in general. The Mondego Estuary is a nursery area for this species, with individuals under $7.0 \mathrm{~mm} \mathrm{CL}$ (approximately one year) accounting for $98 \%$ of the population. Absence of older individuals is due to seawards migrations and rare entrances in the estuary, since shrimps are known to migrate periodically between shallower (warm season) and deeper waters (cold season) (Temming, 2002).

Population structure analysis through frequency distributions is limited by many factors, as was reported by Beukema (1992). The almost continuous settlement of post-larvae is reflected in long recruitments that may last for five months, which makes it difficult to distinguish and separate reproductive pulses. The gradual disappearance of shrimps with a CL>7.0 mm does not allow accurate conclusions to be drawn on the biological cycle or evaluations to be made of older shrimps' contribution to new recruitments. The combination of these factors hampers and restricts analysis of growth, underestimating rates. Though they are flexible processes in time, duration, distance and participa- tion (Boddeke, 1976), few doubts persist on the function of these seasonal migration patterns in juveniles as well as in adults, as they most likely increase growth rates and reproduction success (Kuipers and Dapper, 1981). Two main annual peaks of immature shrimps occurred, showing that the entrance of individuals in the Mondego Estuary population is made in two main recruitment periods. Through modal analysis it was possible to build the population structure according to this premise and synchronise the species life cycle, especially with the occurrence of berried females, temperaturedependent egg development and planktonic larvae (unpublished data). Spring settlement of post-larvae with $5 \mathrm{~mm}$ TL started in April 2004 and March 2005, which is earlier than in northern areas (Table 3), and extended until late August. During spring/summer spawning occurs almost continuously and the duration of the recruitments may correspond to several reproductive pulses that were not distinguishable.

Another recruitment identified in late autumn (November-December) was less intense but had implications for the species' life cycle. A similar pattern has been described only for the German Wadden Sea, where a settlement takes place in January (del Norte-Campos and Temming, 1998). Besides variations among European populations and the differences described in the Mediterranean Sea populations, the recruitment pattern found in the $o$ Mondego Estuary is unique and represents a latitudinal variation in the species' life cycle. The Mondego $C$. crangon population, located on the south range of the species distribution in the Atlantic, is probably conditioned by mild temperatures and lower thermal amplitude.

Due to a warm temperate climate, growth was essentially linear since no seasonal variations in the growth of the cohorts were observed. Post-larval growth was higher than the absolute growth rate, but these values were far below those observed in other systems (Table 3). Growth of crustaceans is a function of two components: the duration of the intermoult period and the increase in size at each moult. However, a conjunction of precocious sexual maturity and almost continuous recruitment may help to explain the growth rates calculated for the Mondego Estuary. With reproduction activity beginning as early as 6 months old and almost continuous spawning patterns, growth rates achieved minimum values, reflecting meta- 
TABLE 3. - Comparative summary of several life cycle parameters (growth rate in $\mathrm{mm}$ TL day ${ }^{-1}$ ) of $C$. crangon populations according to the latitudinal variation.

\begin{tabular}{|c|c|c|c|c|c|}
\hline Reference & Location & Breeding season & Spawning & $\begin{array}{l}\text { Settlement / } \\
\text { recruitment }\end{array}$ & Growth rate \\
\hline Pihl, 1982 & $\begin{array}{l}\text { Gullmarsvik and Sandvik, } \\
\text { Swedish west coast }-58^{\circ} / 57^{\circ} \mathrm{N}\end{array}$ & & & $\begin{array}{c}\text { one: spring } \\
\text { (2nd half Jun/Jul) }\end{array}$ & \\
\hline Oh, 1999; 2004 & $\begin{array}{l}\text { Port Erin Bay, Isle of Man } \\
\text { Irish Sea }-54^{\circ} \mathrm{N}\end{array}$ & $\begin{array}{l}\text { nearly all year } \\
\text { (main: Jan-Jun) }\end{array}$ & $\begin{array}{l}\text { two periods } \\
\text { (winter to early }\end{array}$ & $\begin{array}{l}\text { one major } \\
\text { recruitment: }\end{array}$ & \\
\hline $\begin{array}{l}\text { del Norte-Campos, } \\
1998\end{array}$ & $\begin{array}{l}\text { Meldorf, Eider and Tumlau, } \\
\text { German Wadden Sea }-54^{\circ} \mathrm{N}\end{array}$ & & $\begin{array}{l}\text { spring / summer) } \\
\text { two periods } \\
\text { (winter to early } \\
\text { spring / summer) }\end{array}$ & $\begin{array}{c}\text { May/Aug } \\
\text { almost continuous: } \\
\text { May, Jun/Oct } \\
\text { and Jan }\end{array}$ & $0.23 \pm 0.08$ \\
\hline Kuipers, 1981 & $\begin{array}{l}\text { Balgzand, Dutch } \\
\text { Wadden Sea }-53^{\circ} \mathrm{N}\end{array}$ & Jan-Sep & $\begin{array}{l}\text { two periods } \\
\text { (winter to early } \\
\text { spring / summer) }\end{array}$ & $\begin{array}{l}\text { one: Apr/May } \\
\text { (peak: May/Jun) }\end{array}$ & 0.23 \\
\hline Beukema, 1992 & $\begin{array}{l}\text { Balgzand, Dutch } \\
\text { Wadden Sea }-53^{\circ} \mathrm{N}\end{array}$ & & $\begin{array}{l}\text { one: Apr/May } \\
\text { (Apr after mild winters, } \\
\text { May after cold winters) }\end{array}$ & (post-larvae) & $0.2-0.5$ \\
\hline Cattrijsse, 1997 & $\begin{array}{l}\text { Westerschelde estuary } \\
\text { South-west Netherlands }-51^{\circ} \mathrm{N}\end{array}$ & & & & $\begin{array}{c}0.25-0.39 \\
\text { (post-larvae) }\end{array}$ \\
\hline Henderson, 1987 & $\begin{array}{l}\text { Severn estuary / Bristol Channel } \\
\text { West coast England/Wales }-51^{\circ} \mathrm{N}\end{array}$ & Jan-Aug & $\begin{array}{l}\text { two periods } \\
\text { (winter to early } \\
\text { spring / summer) }\end{array}$ & & \\
\hline Heerebout, 1974 & $\begin{array}{l}\text { Rhine, Meuse and Scheldt } \\
\text { estuaries, The Netherlands - } \\
51^{\circ} \mathrm{N}\end{array}$ & $\begin{array}{l}\text { Two main periods: } \\
\text { end Oct-Mar / } \\
\text { end Mar-Aug }\end{array}$ & & & \\
\hline Amara, 2003 & $\begin{array}{l}\text { La Canche estuary } \\
\text { North coast France }-50^{\circ} \mathrm{N}\end{array}$ & & & $\begin{array}{l}\text { one: mid April- } \\
\text { late August } \\
\text { (peak: early Jun) }\end{array}$ & 0.163 \\
\hline Marchand, 1981 & $\begin{array}{l}\text { Loire estuary } \\
\text { West coast France }-47^{\circ} \mathrm{N}\end{array}$ & Mar-Aug & & $\begin{array}{c}\text { two: May-July / } \\
\text { Aug-Oct }\end{array}$ & $\begin{array}{c}1.03 \text { (female) / } \\
0.67 \text { (male) }\end{array}$ \\
\hline Present study & $\begin{array}{l}\text { Mondego estuary } \\
\text { West coast Portugal }-40^{\circ} \mathrm{N}\end{array}$ & & $\begin{array}{l}\text { two periods: winter } \\
\text { (offshore) spring / } \\
\text { summer (in the estuary) }\end{array}$ & $\begin{array}{l}\text { two: Nov-Dec / } \\
\text { Mar-Aug } \\
0.06 \text { (cohort) }\end{array}$ & $\begin{array}{c}0.07-0.08 \\
\text { (post-larvae) }\end{array}$ \\
\hline Labat, 1977 & $\begin{array}{l}\text { Bages-Sigean lagoon complex } \\
\text { Mediterranean Sea }-43^{\circ} \mathrm{N}\end{array}$ & Nov-Apr & & one: Apr/May & \\
\hline $\begin{array}{l}\text { Crivelli, } 1982 \text { / } \\
\text { Gelin, } 2000\end{array}$ & $\begin{array}{l}\text { Vaccarès lagoon complex } \\
\text { Mediterranean Sea }-43^{\circ} \mathrm{N}\end{array}$ & Nov-Apr & one period & Jun/Sep & \\
\hline
\end{tabular}

bolic costs associated with reproductive activities (ovarian maturation and egg care) plus a cessation of moulting during the spawning period (Oh et al., 1999) because if a berried female moults before the eggs have hatched the eggs will be lost (Boddeke, 1976).

There are seasonal fluctuations in abundance in the $C$. crangon population, with peak abundance in summer (July to August). Maximum abundances were not coincident with the maximum water temperature (in disagreement with Oh et al., 1999), showing less dependence on this parameter probably due to lower thermic amplitude. Nevertheless, a constant pattern was observed with varying intensity in the peaks. Production estimates were different between years and were much lower than values found in other European systems, but with similar P/B ratios: $2.5 \mathrm{~g}$ AFDW m ${ }^{-2} \mathrm{y}^{-1}(\mathrm{P} / \mathrm{B}-8.3)$ (Kuipers and Dapper, 1981) and $2.3 \mathrm{~g} \mathrm{AFDW} \mathrm{m} \mathrm{g}^{-2} \mathrm{y}^{-1}$ (Pihl and Rosenberg, 1982), suggesting that the species contribution to the system varies between latitudes but always maintaining a high $\mathrm{P} / \overline{\mathrm{B}}$ ratio.

\section{Distribution and abundance patterns}

In a highly dynamic system such as the Mondego Estuary, environmental parameters seem to have great influence on the spatial and seasonal distribution of $C$. crangon population, with the particular circumstance of the exceptional conditions found in the winter of 2004/2005. River runoff, besides conditioning salinity changes, is known to play an important role in local planktonic production of coastal waters (Siegel et al., 2005). The distribution of shrimps appears in response to salinity changes (Lloyd and Yonge, 1947), but models show that oxygen plays a significant role in determining predrought abundance (Attrill and Power, 2000). In the CCA diagram, these variables overlap and influence above all the distribution of males with a lower osmorregulation capacity that are not able to tolerate low salinities (Lloyd and Yonge, 1947). This is confirmed by the low male densities found at upstream stations. Also, temperature has been referred to as the major factor determining not only juvenile dis- 
tribution but also the timing and intensity of recruitments (Beukema, 1992). In contrast to Boddeke (1976), immature prawns seem to be more sensitive to temperature fluctuations than mature individuals. During drought periods, temperature becomes the dominant abiotic influence on species abundance (Attrill and Power, 2000). Post-larval shrimp migrate to the upstream brackish part of the estuary shortly after metamorphosis (Cattrijsse et al., 1997), indicating that a combination of factors affects not only juvenile distribution occurring in lower salinities in warm months (Tiews, 1970) but also the overall catches (Spaargaren, 2000). Females were correlated to fine substratum (silt and mud) and algae cover. Berried females with a CL>7.7 $\mathrm{mm}$ show no clear preferences in the diagram, probably due to sparse and sporadic frequency. Low salinities delay ovarian development (Gelin et al., 2001), so berried females seem to be associated with high salinities, reaching peaks of abundance at station N1.

Spring settlement always occurred in the north arm, but with some variations during the study: in 2003 partition of occurrence occurred, with peaks mainly near the mouth of the estuary; in 2004 postlarvae peaks were observed mainly at station $\mathrm{M}$ and, after a dry winter, settlement in 2005 was observed at the uppermost station (N2). Station S1, the one most affected area by the eutrophication process (Dolbeth et al., 2003; Verdelhos et al., 2005), showed abundance minimums and no evidence of preference for vegetated areas was found (in agreement with Pihl, 1986).

Decapod crustaceans are typical components of estuarine systems and play an important role in their dynamics (McLusky and Elliott, 2004). This study reveals that all species dynamics must be analysed in a latitudinal context in which the contribution of each component can vary according to environmental and climate variables. Moreover, differences between populations' life cycles can also constitute a reference to the evolution of global warming in water masses (see Cabral et al., 2001), and to climate change where extreme weather events like severe drought seem to be more frequent (Mirza, 2003).

\section{REFERENCES}

Amara, R. and C. Paul. - 2003. Seasonal patterns in the fish and epibenthic crustaceans community of an intertidal zone with particular reference to the population dynamics of plaice and brown shrimp. Est. Coast. Shelf Sci., 56: 807-818.

Attrill, M.J. and M. Power. - 2000. Effects on invertebrate populations of drought-induced changes in estuarine water quality. Mar. Ecol. Prog. Ser., 203: 133-143.

Baeta, A., H.N. Cabral, J.M. Neto, J.C. Marques and M.A. Pardal. - 2005. Biology, population dynamics and secondary production of the green crab Carcinus maenas (L.) in a temperate estuary. Est. Coast. Shelf Sci., 65: 43-52.

Berghahn, R., M. Waltermath and D. Rijnsdorp. - 1992. Mortality of fish from the by-catch of shrimp vessels in the North Sea. $J$. Appl. Ichthyol., 8: 293-306.

Berghahn, R. and M. Purps. - 1998. Impact of discard mortality in Crangon fisheries on year-class strength of North Sea flatfish species. J. Sea Res., 40: 83-91.

Beukema, J.J. - 1992. Dynamics of juvenile shrimp Crangon crangon in a tidal-flat nursery of the Wadden Sea after mild and cold winters. Mar. Ecol. Prog. Ser., 83: 157-165.

Beukema, J.J. and R. Dekker. - 2005. Decline of recruitment success in cockles and other bivalves in the Wadden Sea: possible role of climate change, predation on postlarvae and fisheries. Mar. Ecol. Prog. Ser., 287: 149-167.

Beyst, B., K. Hostens and J. Mees. - 2002. Factors influencing the spatial variation in fish and macrocrustacean communities in the surf zone of sandy beaches in Belgium. J. Mar. Biol. Ass. U. K., 82: 181-187.

Boddeke, R. - 1976. The seasonal migration of the brown shrimp Crangon crangon. Neth. J. Sea Res., 10: 103-130.

Boddeke, R. - 1982. The occurrence of "winter" and "summer" eggs in the brown shrimp (Crangon crangon) and the impact on recruitment. Neth. J. Sea Res., 16: 151-162.

Cabral, H.N., M.J. Costa and J.P. Salgado. - 2001. Does the Tagus estuary fish community reflect environmental changes? Clim. Res., 18: 119-126.

Cabral, H.N., C.M. Teixeira, R. Gamito and M.J. Costa. - 2002. Importance of discards of a beam trawl fishery as input of organic matter into nursery areas within the Tagus estuary. Hydrobiologia, 475/476: 449-455.

Cardoso, P.G., A.I. Lillebø, M.A. Pardal, S.M. Ferreira and J.C. Marques. -2002 . The effect of different primary producers on Hydrobia ulvae population dynamics: a case study in a temperate intertidal estuary. J. Exp. Mar. Biol. Ecol., 277: 173-195.

Cardoso, P.G., A. Brandão, M.A. Pardal, D. Raffaelli and J.C. Marques. - 2005. Resilience of Hydrobia ulvae populations to anthropogenic and natural disturbances. Mar. Ecol. Prog. Ser., 289: 191-199.

Cassie, R.M. - 1963. Tests of significance for probability paper analysis. N.Z.Sci. Rev., 6: 474-482.

Cattrijsse, A., H.R. Dankwa and J. Mees. - 1997. Nursery function of an estuarine tidal marsh for the brown shrimp Crangon crangon. J. Sea Res., 38: 109-121.

Costa, M.J. and H.N. Cabral. - 1999. Changes in the Tagus nursery function for commercial fish species: some perspectives for management. Aquat. Ecol., 33: 287-292.

Crivelli, A.J. - 1982. Biology of Three Malacostraca (Decapoda) in a Mediterranean Lagoon with Particular Emphasis on the Effect of Rapid Environmental Changes on the Activity (Catchability) of the Species. Est. Coast. Shelf Sci., 15: 591-604.

del Norte-Campos, A.G.C. and A. Temming. - 1998. Population dynamics of the brown shrimp Crangon crangon L., in shallow areas of the German Wadden Sea. Fish. Manage. Ecol., 5: 303-322.

Dolbeth, M., M.A. Pardal, A.I. Lillebø, U. Azeiteiro and J.C. Marques. - 2003. Short- and long-term effects of eutrophication on the secondary production of an intertidal macrobenthic community. Mar. Biol., 143: 1229-1238.

Gamito, R. and H. Cabral. - 2003. Mortality of brown-shrimp discards from the beam trawl fishery in the Tagus estuary, Portugal. Fish. Res., 63: 423-427.

Gelin, A., A. Crivelli, E. Rosecchi and P. Kerambrun. - 2001. Can salinity changes affect reproductive success in the brown shrimp Crangon crangon? J. Crust. Biol., 21: 905-911.

Hartsuyker, L. - 1966. Daily tidal migrations of the shrimp Crangon crangon L. Neth. J. Sea Res., 3: 52-67.

Henderson, P.A. and R. H. A. Holmes. - 1987. On the population biology of the common shrimp Crangon crangon (L.) (Crustacea: Caridea) in the Severn Estuary and Bristol Channel. J. Mar. Biol. Ass. U. K., 67: 825-847. 
Janssen, G.M. and B.R. Kuipers. - 1980. On tidal migration in the shrimp Crangon crangon. Neth. J. Sea Res., 14: 339-346.

Kamermans, P. and H.J. Huitema. - 1994. Shrimp (Crangon crangon L.) browsing upon siphon tips inhibits feeding and growth in the bivalve Macoma balthica (L.). J. Exp. Mar. Biol. Ecol., 175: 59-75.

Kuipers, B. and R. Dapper. - 1981. Production of Crangon crangon in the tidal zone of the Dutch Wadden Sea. Neth. J. Sea Res., 15: 33-53.

Labat, J.-P. - 1977. Écologie de Crangon crangon (L.) (Decapoda, Caridea) dans un étang de la côte languedocienne I. Croissance, reproduction, migrations mer/etang. Vie Milieu, 27: 273-292.

Leitão, R., F. Martinho, J.M. Neto, H. Cabral, J.C. Marques and M.A. Pardal. - 2006. Feeding ecology, population structure and distribution of Pomatoschistus microps (Krøyer, 1838) and Pomatoschistus minutus (Pallas, 1770) in a temperate estuary, Portugal. Est. Coast. Shelf Sci., 66: 231-239.

Lloyd, A. and C.M. Yonge. - 1947. The biology of Crangon crangon L. in the Bristol Channel and Severn Estuary. J. Mar. Biol. Ass. U. K., 26: 626-661.

Martinho, F., R. Leitão, J. Neto, H.N. Cabral, J.C. Marques and M.A. Pardal. - (in press) The use of nursery areas by juvenile fish in a temperate estuary, Portugal. Hydrobiologia.

Martins, I., M.A. Pardal, A.I. Lilleb $\varnothing$, M.R. Flindt and J.C. Marques. - 2001. Hydrodynamics as a Major Factor Controlling the Occurrence of Green Macroalgal Blooms in a Eutrophic Estuary: A Case Study on the Influence of Precipitation and River Management. Est. Coast. Shelf Sci., 52: 165-177.

McLusky, D.S. and M. Elliott. - 2004. The estuarine ecosystem: ecology, threats and management. Oxford University Press, Oxford.

Mirza, M.M.Q. - 2003. Climate change and extreme weather events: can developing countries adapt? Clim. Pol., 3: 233-248.

Nogueira, A.J. - 1992. ANAMOD - Extracção dos componentes modais de distribuições de frequências de variáveis biométricas. Provas de aptidão pedagógica e capacidade científica. Univ. Coimbra, Portugal

Oh, C.-W., R.G. Hartnoll and R.D.M. Nash. - 1999. Population dynamics of the common shrimp, Crangon crangon (L.), in Port Erin Bay, Isle of Man, Irish Sea. ICES J. Mar. Sci., 56: 718-733.

Oh, C.-W., R.G. Hartnoll and R. D.M. Nash. - 2001. Feeding ecology of the common shrimp Crangon crangon in Port Erin Bay, Isle of Man, Irish Sea. Mar. Ecol. Prog. Ser., 214: 211-223.

Oh, C.-W. and R.G. Hartnoll. - 2004. Reproductive biology of the common shrimp Crangon crangon (Decapoda: Crangonidae) in the central Irish Sea. Mar. Biol., 144: 303-316.

Pardal, M.A., J.C. Marques, I. Metelo, A.I. Lilleb $\emptyset$ and M.R. Flindt. - 2000. Impact of eutrophication on the life cycle, population dynamics and production of Ampithoe valida (Amphipoda) along an estuarine spatial gradient (Mondego estuary, Portugal). Mar. Ecol. Prog. Ser., 196: 207-219.
Pardal, M.A., P.G. Cardoso, J.P. Sousa, J.C. Marques and D. Raffaelli. - 2004. Assessing environmental quality: a novel approach. Mar. Ecol. Prog. Ser., 267: 1-8.

Pascoe, S. and A. Revill. - 2004. Costs and Benefits of Bycatch Reduction Devices in European Brown Shrimp Trawl Fisheries. Environ. Resource Econ. 27: 43-64.

Pihl, L. and R. Rosenberg. - 1982. Production, abundance, and biomass of mobile epibenthic marine fauna in shallow waters, Western Sweden. J. Exp. Mar. Biol. Ecol., 57: 273-301.

Pihl, L. and R. Rosenberg. - 1984. Food selection and consumption of the shrimp Crangon crangon in some shallow marine areas in western Sweden. Mar. Ecol. Prog. Ser., 15: 159-168.

Pihl, L. - 1985. Food selection and consumption of mobile epibenthic fauna in shallow marine areas. Mar. Ecol. Prog. Ser., 22: $169-179$.

Pihl, L. - 1986. Exposure, vegetation and sediment as primary factors for mobile epibenthic faunal community structure and production in shallow marine soft bottom areas. Neth. J. Sea Res., $2075-83$.

Siegel, V., J. Groger, T. Neudecker, U. Damn and S. Jansen. 2005. Long-term variation in the abundance of the brown shrimp Crangon crangon (L.) population of the German Bight and possible causes for its interannual variability. Fish. Oceanogr., 14: 1-16.

Spaargaren, D.H. - 2000. Seasonal and annual variations in the catches of Crangon crangon, (L., 1758) (Decapoda, Natantia) near the coast of Texel, The Netherlands. Crustaceana, 73: 547-563.

Temming, A. and U. Damm. - 2002. Life cycle of Crangon crangon in the North Sea: a simulation of the timing of recruitment as a function of the seasonal temperature signal. Fish. Oceanogr., 11: 45-58

Ter Braak, C. and P. Smilauer. - 1998. CANOCO reference manual and user's guide to Canoco for Windows: software for Canonical Community Ordination (version 4). Microcomputer Power, Ithaca, NY, USA.

Tiews, K. - 1970. Synopsis of biological data on the common shrimp, Crangon crangon (Linnaeus, 1758). FAO Fish. Rep., 4: 1167-1224.

van Donk, E. \& P.J. De Wilde (1981). Oxygen consumption and motile activity of the brown shrimp Crangon crangon related to temperature and body size. Neth. J. Sea Res., 15: 54-64.

Verdelhos, T., J.M. Neto, J.C. Marques and M.A. Pardal. - 2005. The effect of eutrophication abatement on the bivalve Scrobicularia plana. Est. Coast. Shelf Sci., 63: 261-268.

Wennhage, H. and R.N. Gibson. - 1998. Influence of food supply and a potential predator (Crangon crangon) on settling behaviour of plaice (Pleuronectes platessa). J. Sea Res., 39 103-112

Scient. ed.: J.B. Company.

Received September 19, 2006. Accepted March 12, 2007.

Published online June 28, 2007. 